\title{
Histopathology of the digestive gland-gonad complex of the marine prosobranch Littorina littorea exposed to cadmium
}

\author{
Ion A. Marigómez, Miren P. Cajaraville, Eduardo Angulo \\ Zitologi eta Histologi Laborategia, Biologia Zelularra eta Zientzia Morfologikoen Saila, Zientzi Fakultatea, Euskal Herriko \\ Unibertsitatea, 644 P. K., E-48080 Bilbo, Spain
}

\begin{abstract}
A histopathological investigation of the digestive gland-gonad complex of winkles that were experimentally exposed to sublethal concentrations of cadmium (Cd) was performed. The structural integrity of digestive and basophilic cells of the digestive gland drastically changed such that both cell types became morphologically indistinguishable at the light microscope level. The volume density (VD) of hemocytes and pore cells located both around the stomach and in interstitial connective tissues were significantly increased due to Cd-exposure. Both hemocytic diapedesis across the epithelia of digestive tubules and stomach, and occasional disintegration of both epithelia appear to be related to $\mathrm{Cd}$-exposure. The stress response caused by acclimation to laboratory conditions leads to the induction of spawning activity and masks the likely effect of $\mathrm{Cd}$ on the gonadal tissue. An intense hemocytic infiltration was observed in gonadal follicles of females exposed to $1.25 \mathrm{mg} \mathrm{Cd}^{-1}$ after $24 \mathrm{~d}$.
\end{abstract}

\section{INTRODUCTION}

The digestive tubule epithelium of the marine prosobranch Littorina littorea primarily consists of digestive and basophilic cells. The digestive cell possesses a system of membrane-bound vesicles of variable content and has been reported to be involved in absorption and intracellular digestion of food material (Merdsoy \& Farley 1973, Pipe 1986). The basophilic cell has a characteristic pyramidal shape and contains apical spherules of proteinaceous material and vacuoles filled with phosphorous-rich granules in the mid-region of the cell (Mason 1983). The basal cytoplasm of basophilic cells is filled with a well-developed rough endoplasmic reticulum and a prominent Golgi body. Although the functional role of basophilic cells remains unclear, they appear to be involved in the synthesis and secretion of proteins, which could contain precursors for digestive enzymes thought to be involved in extracellular digestion (Mason 1983).

As in many other molluscs, the digestive glandgonad complex has recently been shown to be a major accumulation organ of $\mathrm{Cd}$ in Littorina littorea (Marigómez \& Ireland 1989). Cd is reported to be sequestered in the lysosomal system of the digestive cells of Pecten maximus (Ballan-Dufrancais et al. 1985).
Mytilus edulis (Janssen \& Scholz 1979, Janssen \& Ertelt-Janssen 1983), and L. littorea (Marigómez et al. 1990). Hemacytes of Crassostrea gigas, P. maximus and L. littorea (Ballan-Dufrancais et al. 1985, Martoja \& Martin 1985, Marigómez et al. 1990) are also capable of accumulating the metal, while hemocytes of $M$. edulis and Ostrea edulis show no such activity (Janssen \& Scholz 1979, George et al. 1983).

Although much effort has been directed at determining accumulation patterns and tissue distribution of $\mathrm{Cd}$, to our knowledge, there have been few efforts at describing the toxic effects of $\mathrm{Cd}$ at the cellular level. Therefore, the present experimental study was designed to determine the histological changes induced in the digestive and basophilic cells of the digestive gland of winkles. Attention was also paid to hemocytes, which play an important role in the distribution and storage of $\mathrm{Cd}$, and participate in various key physiological functions (Cheng 1984, Marigómez et al. 1990)

Tissue changes in the gonadal follicles, which are located among digestive tubules within the visceral mass, were also studied in the present work. Although a number of studies have been carried out on the effects of $\mathrm{Cd}$ on marine bivalve reproduction (Sunila 1984, Pascual et al. 1987, Gould et al. 1988, Kluytmans 
et al. 1988), similar studies on gastropods are lacking In addition, the reported results are apparently inconsistent. Gould et al. (1988) reported that Cd stimulates early gamete maturation and spawning in the scallop Placopecten magellanicus, while Kluytmans et al. (1988) found that $\mathrm{Cd}$ inhibits initial follicle development but subsequently has a stimulating effect on the spawning frequency of the mussel Mytilus edulis. No correlation between metal content and gonad development was concluded in $M$. edulis from different wild populations (Pascual et al. 1987).

\section{MATERIALS AND METHODS}

Littorina littorea were purchased from a commercial dealer (French Fisheries, collected from Clew Bay, $53^{\circ} 52^{\prime} \mathrm{N}, 9^{\circ} 37^{\prime} \mathrm{W}$, Eire). Specimens ranging from 20 to $23 \mathrm{~mm}$ shell height were selected and maintained in seawater ( $36 \%$ salinity) at 16 to $18^{\circ} \mathrm{C}$ for $1 \mathrm{wk}$ before experimentation. Groups of winkles (16 ind. $1^{-1}$ ) were subjected to cadmium (as $\mathrm{CdCl}_{2}$ ) in the sublethal concentration range of $0,0.5$ and $1.25 \mathrm{mg} \mathrm{Cd} \mathrm{l}^{-1}$ (Marigómez et al. 1987) in a double series for $27 \mathrm{~d}$. The highest concentration used represents the threshold of sublethal response (Marigómez et al. 1987), while the intermediate $\mathrm{Cd}$ concentration is close to the value recorded in some highly polluted estuarine waters (Sprague 1986). Winkles were continuously fed on Fucus vesiculosus. The external medium and food were changed every second day. Under these conditions Cd concentration in the digestive gland-gonad complex was dose and time dependent, this organ being the main site for metal accumulation under high cadmium exposure conditions (Marigómez \& Ireland 1989).

Up to 4 winkles were removed from each $\mathrm{Cd}$-exposure group after $4,6,10,13,17,20,24$ and $27 \mathrm{~d}$ treatment. Control specimens were removed only after $4,6,20$ and $24 \mathrm{~d}$. The digestive gland-gonad complex was dissected out and fixed in Bouin's fluid $\left(32 \mathrm{~h}, 5^{\circ} \mathrm{C}\right.$ ) (Martoja \& Martoja-Pierson 1970). Paraffin sections $(8 \mu \mathrm{m})$ were stained with hematoxylin and eosin ( $\mathrm{H} \& \mathrm{E}$ ).

The Volume Densities (VD) of eosinophilic hemocytes (Mason 1983. Cajaraville et al. 1990) and connective tissue pore-cells were estimated in 2 zones (neighbouring the stomach and interstitial) of the connective tissue by point counting with the aid of a Weibel graticule (Multipurpose Test System, M-168) (Weibel 1979). A drawing-tube attachment on a Nikon Optiphot microscope was used to produce a magnification of $\times 1100$. Point counting was carried out in 5 randomly selected fields from up to 4 non-serial sections resulting in the examination and quantification of 20 fields comprising an area of $20 \times 18000 \mu^{2}$ and 3360 points per treatment group. The number of segment edges of the graticule lying on hemocytes (Xh) and on pore cells $(\mathrm{Xpc})$, as well as the number of graticule points lying on connective tissue $(\mathrm{m})$, were recorded. Thus, according to Weibel (1979), the volume density of each cell type (VDh and VDpC) was calculated on the basis of a hypothetical isotropy of the studied cells, as derived from the descriptions made by Mason (1983), resulting in the following formulas:

$$
\begin{gathered}
\mathrm{VDh}=\mathrm{Xh} / \mathrm{m} \\
\mathrm{VDpc}=\mathrm{Xpc} / \mathrm{m}
\end{gathered}
$$

\section{RESULTS}

The structure of the cell types comprising the digestive tubules of Littorina littorea changes as a result of exposure to $\mathrm{Cd}$. Digestive and basophilic cells are affected differently.

The effect of $\mathrm{Cd}$ on digestive cells is seen as an intense vacuolisation of the basal one third of the cells. Vacuoles may appear empty, as homogeneous and slightly basophilic, or more frequently, they appear as lipofuscin-like yellow granules. When winkles were

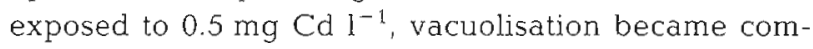
mon after $10 \mathrm{~d}$ (Fig. 1) but the response did not occur in all specimens. Vacuolisation was already evident after

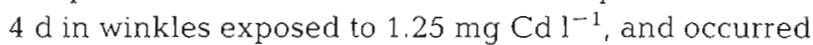
as a general phenomenon in all treated specimen. After $17 \mathrm{~d}$ exposure to $1.25 \mathrm{mg} \mathrm{Cd}^{-1}$, a loss of apical cytoplasm associated with a massive extrusion of eosinophilic granules from digestive cells was observed (Figs. 2 and 3). After the 20th day of exposure to $1.25 \mathrm{mg} \mathrm{Cd}$ $1^{-1}$, a decline in the numbers of digestive cells was observed. The remaining digestive cells had lost their structural integrity at this time, and digestive tubules were primarily composed of basophilic cells laying on a thickened basal lamina (histological sense) (Fig. 4). Simultaneous hemocyte diapedesis was intense across the digestive gland epithelium (Fig. 5). Such extreme instances of digestive cell degeneration were never observed in winkles exposed to $0.5 \mathrm{mg} \mathrm{Cd} \mathrm{l}^{-1}$

Two types of responses to $\mathrm{Cd}$ exposure were observed in basophilic cells. The first consisted of an increasing occurrence of vacuoles containing a homogeneous basophilic material or yellow granules. This response was observed after 10 and $4 \mathrm{~d}$ exposure to 0.5 and $1.25 \mathrm{mg} \mathrm{Cd}^{-1}$, respectively. The second alteration observed was cellular hypertrophy with a concomitant loss of the normal basophilic character of this cell type. Both phenomena appear related since the loss of basophily was first observed at the cell apex simultaneously to initial. evidences of increased size. These changes occurred gradually, and hence, the coexistence of normal and modified basophilic cells in 


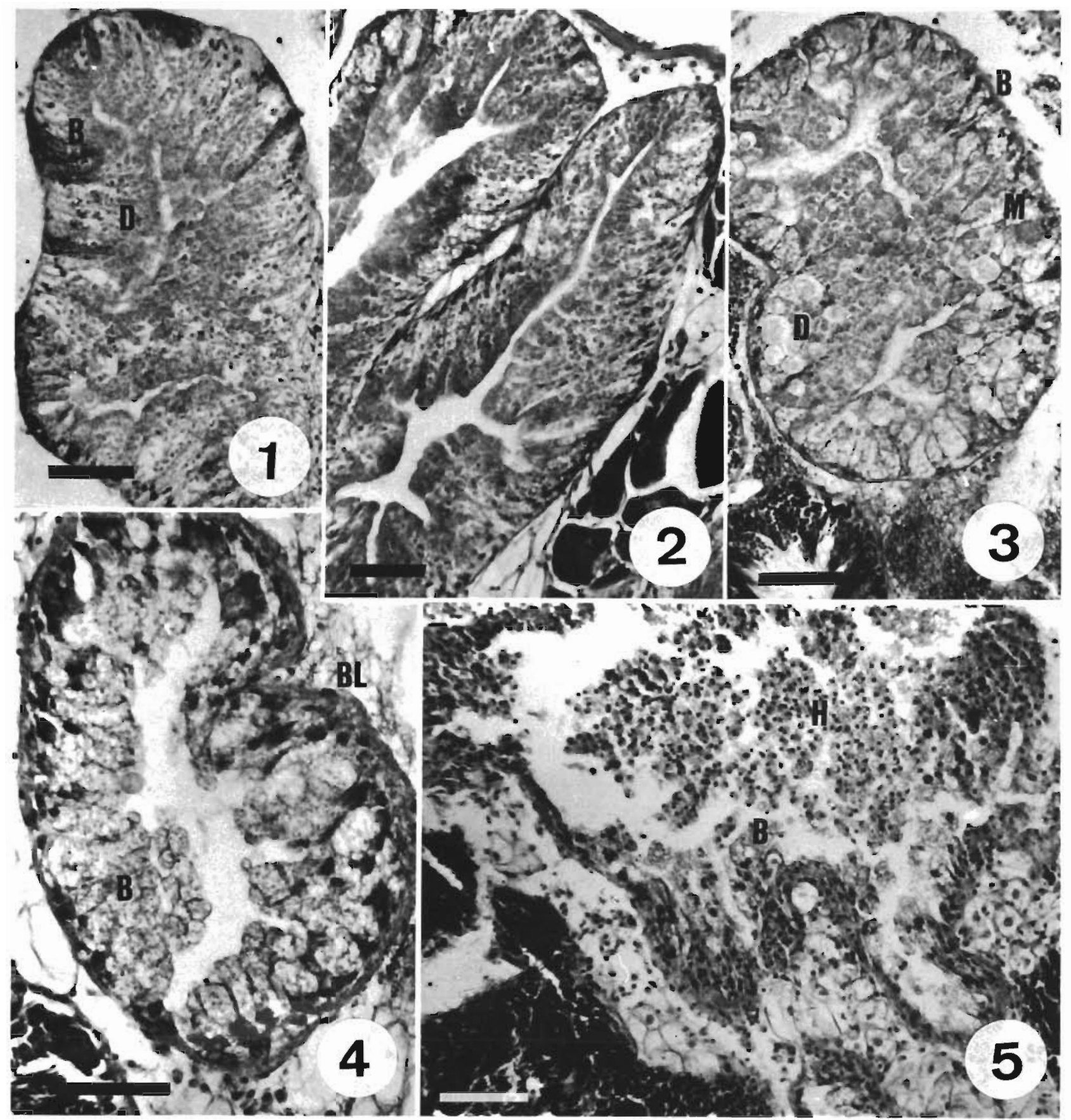

Figs. 1 to 5. Littorina littorea. Scale bars $=50 \mu \mathrm{m}$. Fig. 1. Paraffin-section of digestive tubule of a winkle exposed to $0.5 \mathrm{mg} \mathrm{Cd} \mathrm{l}^{-1}$ for $10 \mathrm{~d}$. Note degenerating digestive cells (D) and normal basophilic cells (B). Fig. 2. Digestive tubule of a winkle exposed to 1.25 $\mathrm{mg} \mathrm{Cd} \mathrm{l}^{-1}$ for $24 \mathrm{~d}$. Fig. 3. Digestive tubule of a winkle exposed to $1.25 \mathrm{mg} \mathrm{Cd} \mathrm{l}^{-1}$ for $20 \mathrm{~d}$. Note normal and rarified basophilic cells (B), some mucocytes (M) and degenerated digestive cells (D). Fig. 4. Digestive tubule solely composed of abnormal basophilic

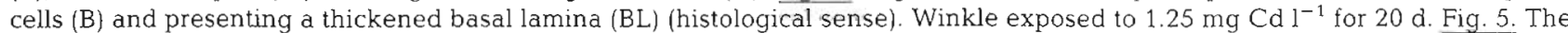
same individual as in Fig. 4. Note that abnormal basophilic cells $(B)$ and hemocytes $(\mathrm{H})$ are the sole cell types observed

the same epithelium was not uncommon (i.e. winkles exposed to $0.5 \mathrm{mg} \mathrm{Cd}^{-1}$ ). When winkles were exposed to $1.25 \mathrm{mg} \mathrm{Cd} \mathrm{l}^{-1}$ for more than $17 \mathrm{~d}$, most of the basophilic cells were altered and constituted the main cell type present in the digestive tubules (Figs, 4 and 5).

The alterations observed in digestive and basophilic cells have been diagrammatically summarized in Fig. 6. 


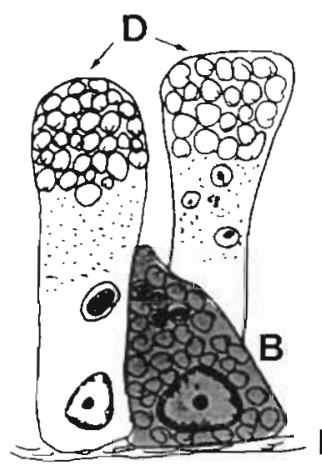

CONTROL

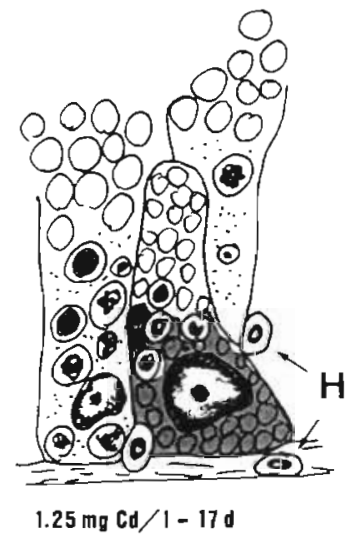

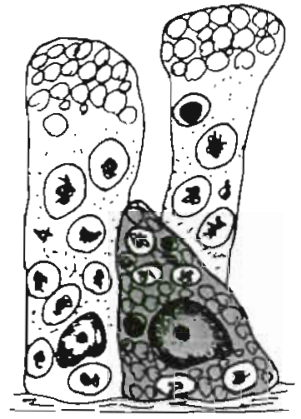

$0.5 \mathrm{mg} \mathrm{Cd} / 1-10 \mathrm{~d}$ on
$1.25 \mathrm{mg} C \mathrm{~d} / \mathrm{I}-3 / 14 \mathrm{~d}$

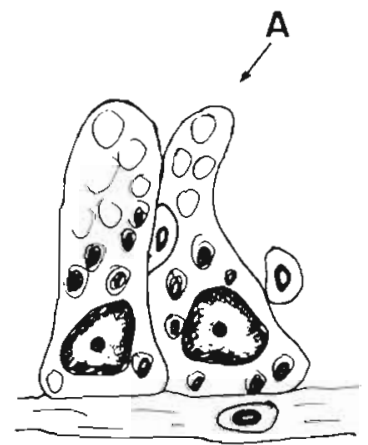

$1.25 \mathrm{mg} d / \mathrm{C}-20 \mathrm{~d}$ on

Fig. 6. Littorina littorea. Diagrammatical representation of changes due to exposure to sublethal concentrations of $\mathrm{Cd}$ in digestive cells (D) and basophilic cells (B) of the digestive gland epithelium. BL: basal lamina; $\mathrm{H}$ : hemocytes; $\mathrm{A}$ : abnormal basophilic cells

Eosinophilic hemocytes presented characteristic vacuoles and some dark granules. Moreover, pseudopodial projections were often observed. These hemocytes were rounded cells ( 8 to $10 \mu \mathrm{m}$ diameter) with a central nucleus (3 to $4 \mathrm{~m}$ diameter). Pore cells were 4 to 6 times bigger in volume, with a laterally displaced nucleus, and possessed brown cytoplasmatic inclusions. On the basis of the stereological study carried out to determine the abundance of hemocytes and pore cells in the connective tissue, and according to the $95 \%$ confidence intervals based on the Student's t test, it is concluded that there was a significant increase in the $\mathrm{VD}$ of both cell types because of Cd-exposure (Figs. 7 and 8).

VD of pore cells in control specimens was higher in the connective tissue underlining the stomach than in the interstitial connective tissue. As a consequence of exposure to $\mathrm{Cd}$ we did not observe a change in the individual size of pore cells. Thus, since the VD of this cell type increased, it indicates that the number of pore cells was higher in Cd-exposed winkles than in control

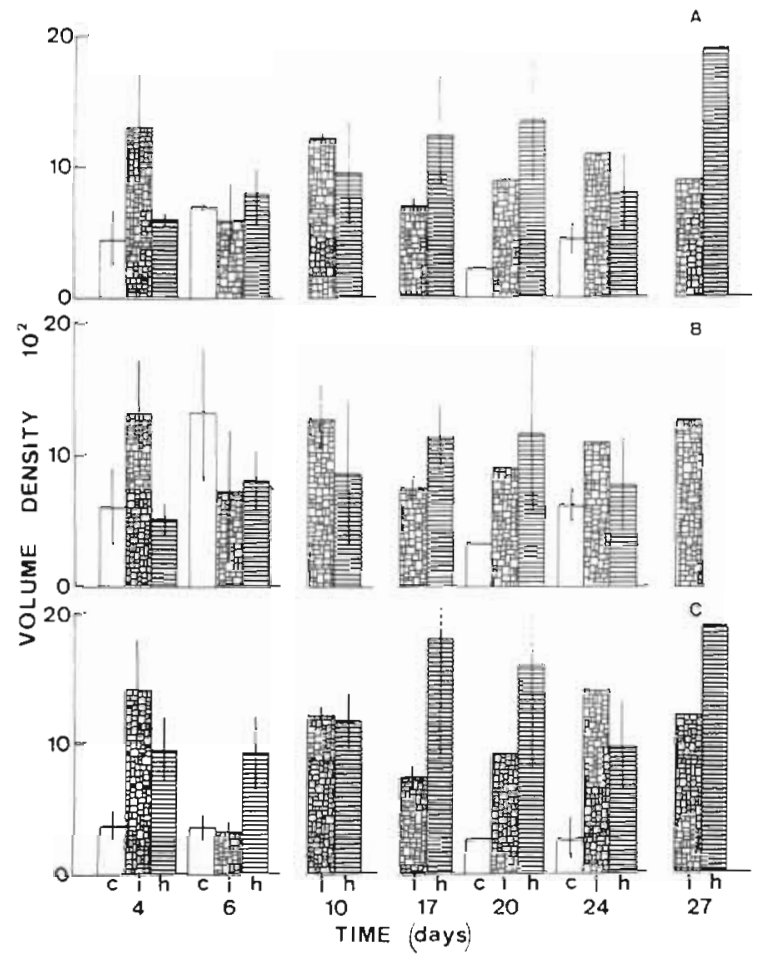

Fig. 7. Littorina littorea. Results of stereological analysis of volume density of eosinophilic hemocytes in: (A) connective tissue of the digestive gland-gonad complex; (B) connective tissue underlining the stomach wall; and (C) interstitial connective tissue. Abbreviations are: (c) control; (i) $0.5 \mathrm{mg} \mathrm{Cd} \mathrm{I}{ }^{-1}$; (h) $1.25 \mathrm{mg} \mathrm{Cd} \mathrm{I}^{-1}$ Control results for Days 10 and 17 are missing

ones. Such an increase was more evident in the connective tissue underlining the stomach epithelium where the response was also prompter than in the interstitial connective tissue. After 6 and $4 \mathrm{~d}$ exposure

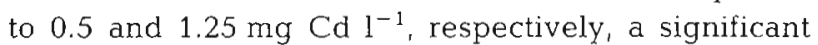
increase was observed in the VD of pore cells located immediately beneath the stomach, while this effect was observed in cells located in the interstitial connective tissue only after 10 and $6 \mathrm{~d}$ exposure to 0.5 and $1.25 \mathrm{mg}$ $\mathrm{Cd} \mathrm{l}^{-1}$, respectively (Fig. 8). The results indicate that pore cells increased in number later in winkles exposed to $0.5 \mathrm{mg} \mathrm{Cd}^{-1}$ than in those exposed to $1.25 \mathrm{mg} \mathrm{Cd}$ $1^{-1}$. However, the values of VD of pore cells were not correlated with environmental concentrations of the metal, nor with exposure time.

A similar trend was observed in the VD of eosinophilic hemocytes of winkles exposed to sublethal concentrations of $\mathrm{Cd}$. VD of this cell type in the connective tissue surrounding the stomach was very high in control specimens. Therefore, the increase in the values of this parameter, associated with Cd-exposure, resulted in less evident changes in this zone of the connective tissue than in the interstitial connective tissue (Fig. 7). As in the case of the VD of pore cells, 


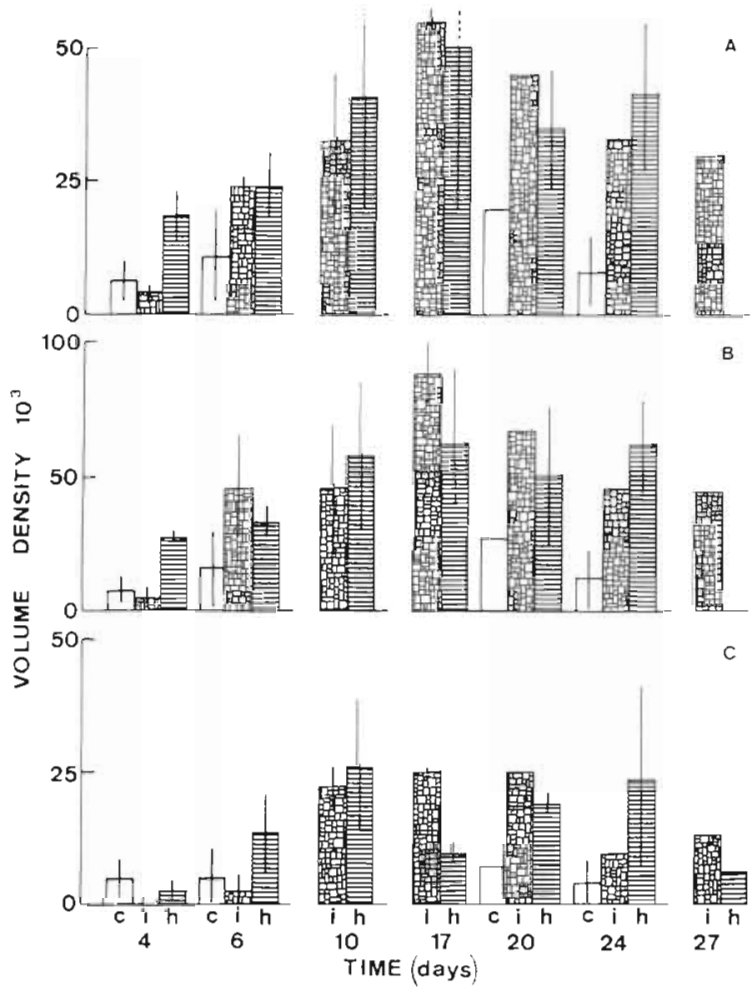

Fig. 8. Littorina littorea. Results of stereological analysis of volume density of pore cells in: (A) connective tissue of the digestive gland-gonad complex; (B) connective tissue underlining the stomach wall; and (C) interstitial connective tissue. See Fig. 7 for further details

changes in the VD of hemocytes were not dependent on Cd concentration or on exposure time (Fig. 8), but it was higher in Cd-exposed winkles than in control ones.

Concomitant to the increase in the VD of eosinophilic hemocytes, blood vessels appeared dilated (Fig. 9), and connective tissue calcium cells (CTCC) located at the periphery of the vessels showed structural disruption. Hemocyte infiltration across CTCC, to reach connective tissues of the visceral mass from blood vessels, was common.

The stomach epithelium of winkles exposed to both experimental concentrations of Cd after $6 \mathrm{~d}$ showed some changes. These changes consisted of a distension/dilation of the cells (Figs. 10 and 11), as evidenced by the rounding of nuclei which appear enlarged in control specimens, and also included an increasing apocrine extrusion from stomach cell apex (Fig. 11). Intensive hemocyte diapedesis across this epithelium was observed in Cd-exposed winkles. After $20 \mathrm{~d}$ exposure to $1.25 \mathrm{mg} \mathrm{Cd} \mathrm{l}^{-1}$, some individuals underwent partial desquamation and disintegration of the stomach epithelium (Fig. 12).

Finally, the male reproductive follicles did not appear to be affected by exposure to $\mathrm{Cd}$. Male follicles presented gametes in different stages of development.
Some follicles were full of immature cells while others presented immature gametes in their periphery and mature spermatozoa in the lumen. A common feature of both control and Cd-exposed male winkles was that the lumen of the follicles appeared empty, indicative of a post-spawning condition. Indeed, spermiducts with mature spermatozoa were observed in several specimens. Female winkles also presented oocytes belonging to different stages of development: from small strongly basophilic oocytes, to large yolked oocytes. Occasionally, groups of hemocytes were found inside female follicles of control and Cd-exposed specimens. Such hemocytic infiltration was spectacular in some

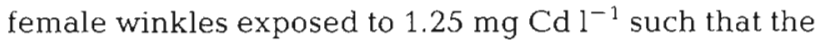
gonadal tissue was replaced by hemocyte masses (Figs. 13 and 14).

\section{DISCUSSION}

Changes in both digestive and basophilic cells of Littorina littorea are dependent upon the external $\mathrm{Cd}$ concentration but no association with exposure time was observed once a certain degree of alteration was reached in the tissues. Our observations indicate that exposure to $1.25 \mathrm{mg} \mathrm{Cd}^{-1}$ causes the breakdown of digestive cells. This is evidenced by an increasing occurrence of vacuoles containing lipofuscin-like material and a subsequent gradual loss of apical cytoplasm. Eventually, these cells show no structural integrity and are indistinguishable from the basophilic cells that comprise the digestive epithelium. The basophilic cells also undergo dramatic gradual changes which involve an increase in cell size. In addition, they lose their typical basophilic staining properties. This condition progresses from the cellular apex and is concomitant with cellular hypertrophy.

The loss of basophily could be related to the disorganization of the rough endoplasmic reticulum (RER), a major constituent of basophilic cells, which has been reported previously in the tissues of various invertebrates exposed to Cd (Janssen \& Ertelt-Janssen 1983, Papathanassiou \& King 1986). Changes in RER organization could be due to exhaustion of the organelle after an intense activity of protein synthesis. Indeed, it has been demonstrated that $\mathrm{Cd}$ induces the synthesis of Cd-binding proteins in Littorina littorea (Langston \& Zhou 1986). On the other hand, the accumulation of Class A metals takes place, primarily, in digestive cells (Janssen \& Ertelt-Janssen 1983, Ballan-Dufrancais et al. 1985). Thus, in conditions of exposure to these metals, the normal intracellular digestion carried out by digestive cells may be disrupted which, in turn, may lead, in basophilic cells, to an enhanced secretion of proteins for extracellular digestion. 
It seems that a certain level of $\mathrm{Cd}$ must be present in the tissues to give rise to the above mentioned morphological changes. Accordingly, Papathanassiou \& King (1986) reported the occurrence of swelling of RER in hepatopancreatic cells of Palaemon serratus after

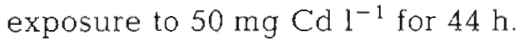

The occurrence of digestive tubules comprised of only basophilic cells has been previously described in mussels (Rasmussen et al. 1983) and winkles (Cajaraville et al. 1990) treated with different organic chemicals. This may indicate that the observed changes are nonspecific and are caused by a general

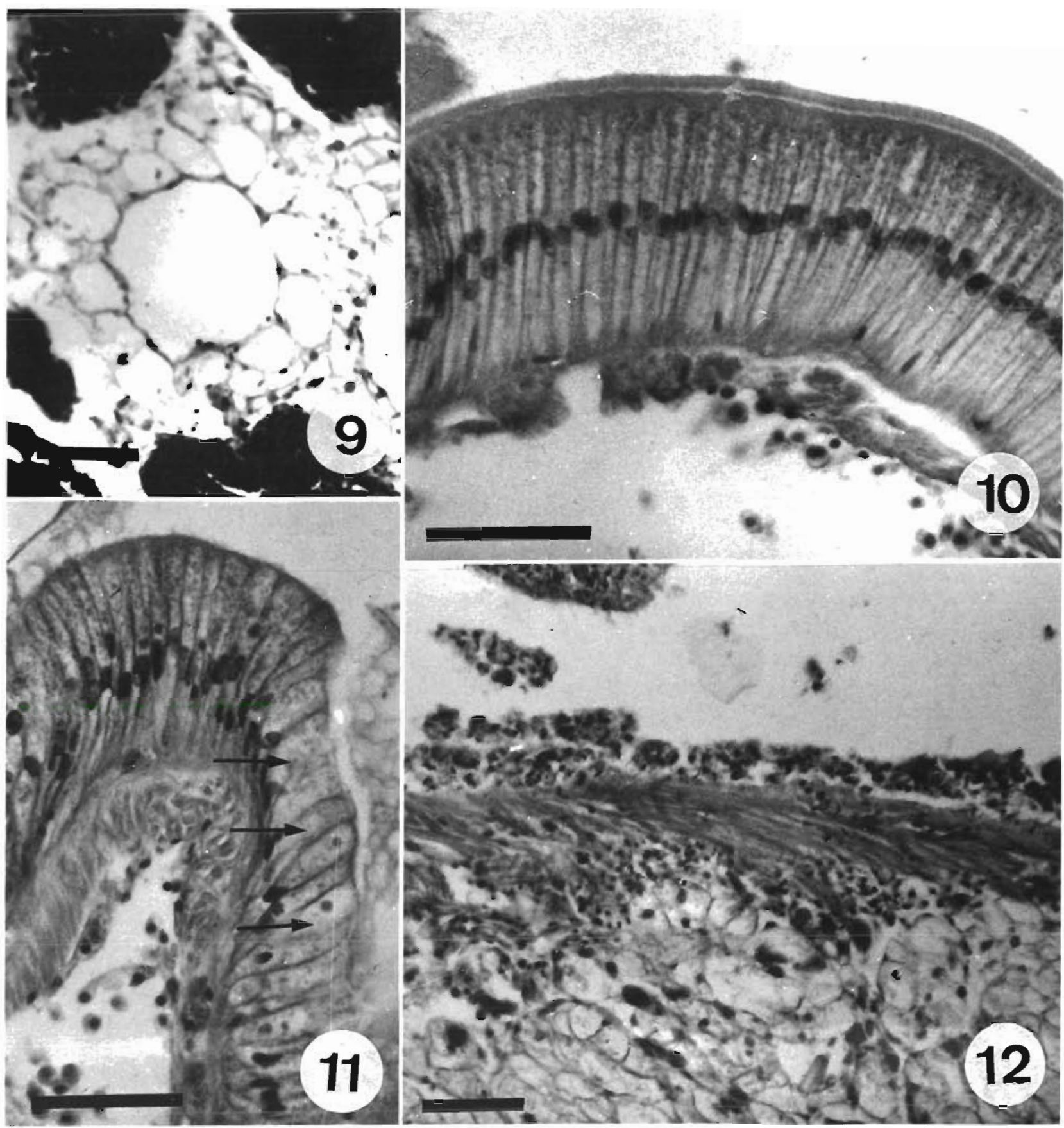

Figs, 9 to 12. Littorina littorea, Fig. 9. CTCC (connective tissue calcium cells) comprising the dilated blood vessel of a winkle

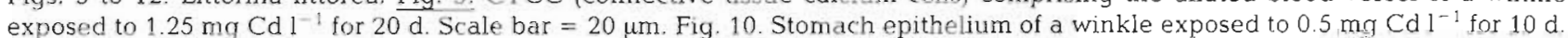
Primary vacuolation of basal. cytoplasm and rounded nuclei, which appear ovate in control winkles, is evident. However, the general aspects of this epithelium are very similar to that of control winkles. Scale bar $=50$ um. Fig. 11. Erosion of the stomach epithelium in a winkle exposed to $1.25 \mathrm{mg} \mathrm{Cd}^{-1}$ for $20 \mathrm{~d}$. Note cytoplasmic evacuation (arrows). Scale bar $=50 \mu \mathrm{m}$. Fig. 12 . Destroyed portion of the stomach epithelium in a winkle exposed to $1.25 \mathrm{mg} \mathrm{Cd} 1^{-1}$ for $20 \mathrm{~d}$. Scale bar $=50 \mu \mathrm{m}$. 


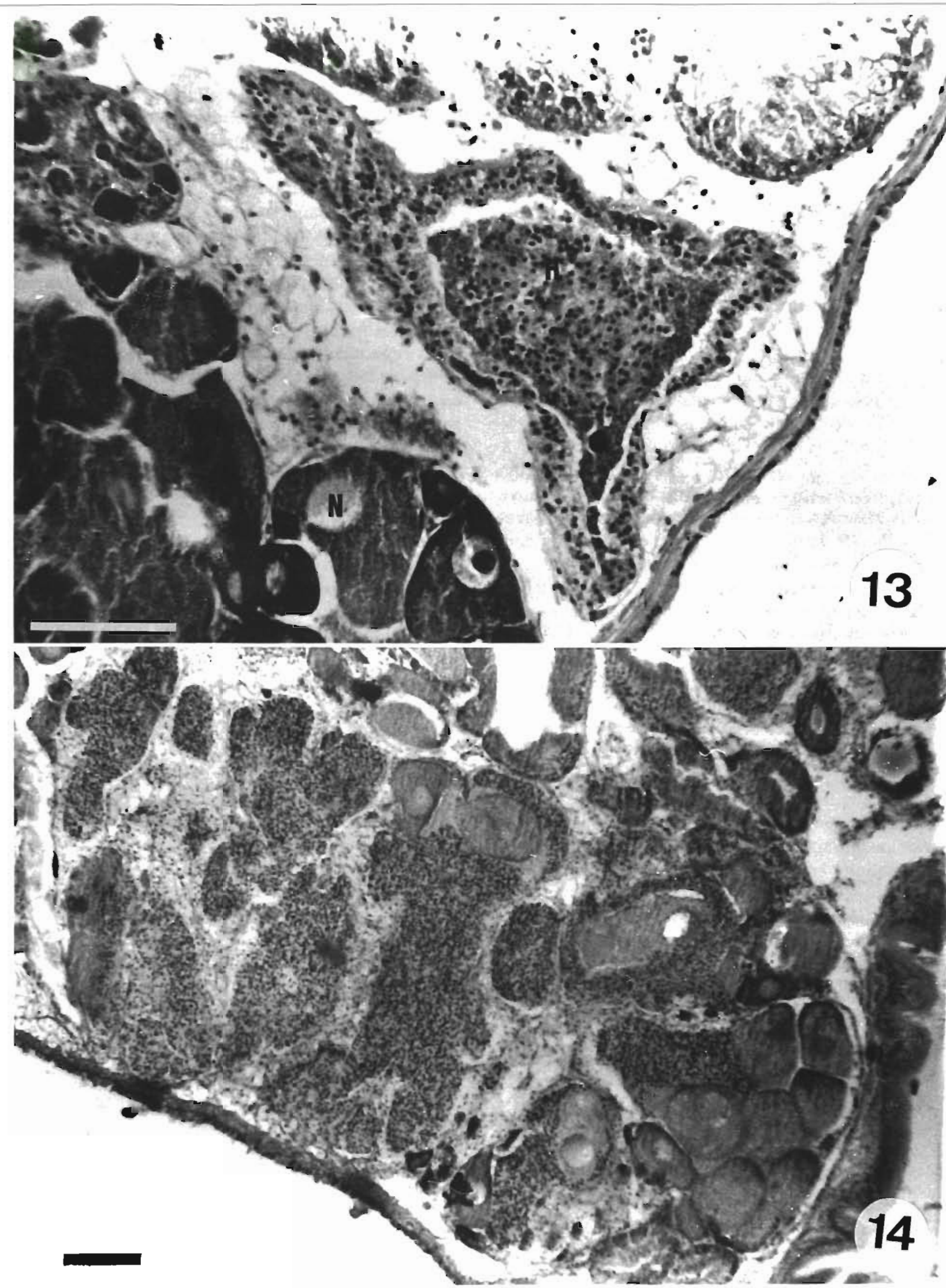

Figs. 13 and 14. Littorina littorea. Fig. 13. Gonadal follicle of a female winkle exposed to $1.25 \mathrm{mg} \mathrm{Cd} 1^{-1}$ for $10 \mathrm{~d}$. Note coexistence of follicles containing hemocyte masses $(\mathrm{H})$ and others with a normal appearance $(\mathrm{N})$. Scale bar $=100 \mu \mathrm{m}$. Fig. 14 . Hemocyte invasion of female gonadal tissue found in one winkle exposed to $1.25 \mathrm{mg} \mathrm{Cd}^{-1}$ for $27 \mathrm{~d}$. Scale bar $=100 \mu \mathrm{m}$ 